Erratum

\title{
Erratum: Jonathan Driedger and Meinard Müller. A Review of Time-Scale Modification of Music Signals. Applied Sciences 2016, 6, 57
}

\author{
Applied Sciences Editorial Office \\ MDPI AG, Klybeckstrasse 64, CH-4057 Basel, Switzerland \\ Academic Editor: Vesa Valimaki \\ Received: 7 March 2015; Accepted: 8 March 2016; Published: 17 March 2016
}

We wish to make the following correction to the published paper [1]. The conference in the title note is incorrect. It should read:

t This paper is an extended version of our paper published in the Proceedings of the International Conference on Digital Audio Effects (DAFx), Erlangen, Germany, 1-5 September 2014.

The error was introduced during production and is not the fault of the authors. We apologize for any inconvenience caused to the readers and authors by this change.

\section{References}

1. Driedger, J.; Müller, M. A Review of Time-Scale Modification of Music Signals. Appl. Sci. 2016, 6, 57. [CrossRef]

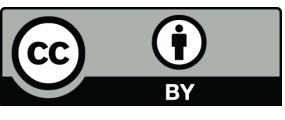

(C) 2016 by the author; licensee MDPI, Basel, Switzerland. This article is an open access article distributed under the terms and conditions of the Creative Commons by Attribution (CC-BY) license (http:/ / creativecommons.org/licenses/by/4.0/). 